\title{
THE MOST COMMON BACTERIAL ISOLATES FROM WOUND SAMPLES - A THREE-YEAR STUDY
}

\author{
Ana Kaftandjieva ${ }^{1}$, Marko Kostovski ${ }^{1}$, Blerta Mehmeti ${ }^{1}$, Gordana Mirchevska ${ }^{1}$ \\ 1 Institute of Microbiology and Parasitology, Faculty of Medicine, Ss. Cyril and Methodius University in Skopje, \\ Republic of North Macedonia
}

Citation: Kaftandjieva A, Kostovski M, Mehmeti B, Mirchevska G. The Most Common Bacteria Isolates Mirchevska G. The Most Common Bacterial Isolates from Wound Samples - a Three-Year Study.Arch Pub 2021; 13 (1)

doi.org/10.3889/aph.2021.5736

Key words: wound samples, resistant bacteria, Staphylococcus aureus, carbapenem-resistant bacteria

*Correspondence: Ana Kaftandjieva. Institute of Microbiology and Parasitology, Faculty of Medicine, Ss. Cyril and Methodius University in Skopje, Republic of North Macedonia

E-mail: akaftandzieva@yahoo.com

Received: 16-Dec-2020; Revised: 27-Fev-2021; Accepted: 1-Mar-2021; Published: 8-June-2021 Copyright: ${ }^{02021 . ~ A n a ~ K a f t a n d j i e v a, ~ M a r k o ~}$ Kostovski, Blerta Mehmeti, Gordana Mirchevska This is an open-access article distributed under the terms of the Creative Commons Attribution License, which permits unrestricted use, distribution, and reproduction in any medium, provided the original author(s) and source are credited.

Competing Interests: The author have declared that no competing interests

\begin{abstract}
The aim of our study was to determine the most common bacteria isolated from wound samples and to compare the frequency of the resistant bacteria isolated over a 3-year period. Material and methods: During a three-year-period (2017-2019) a total of 11,863 wound samples (wound swabs, punctuates, exudates, tissue, etc.) were obtained from the hospitalized patients in the University Clinical Center "Mother Theresa", the City hospital "8th September" and the University Clinic for Surgical Diseases "St. Naum Ohridski" in Skopje. All samples were analyzed at the Institute of Microbiology and Parasitology, Faculty of Medicine, Skopje. They were examined by standard microbiology techniques. Identification and susceptibility of microorganisms were done by both standard methods and automatized Vitek 2 system. Results: Of a total number of samples, which was 3,463 in 2017, 4,127 in 2018 and 4,273 in 2019, positive were 2,068 (60\%), 2,302 (55.8\%) and 2,387 (55.9\%), respectively. Staphylococcus aureus was the most predominant isolate followed by Enterococcus spp, Pseudomonas aeruginosa and E. coli. The percentage of the resistant strains of MRSA, CNSMR and VRE was almost the same in that period. The percentage of ESBL-positive isolates of E. coli and Enterobacter spp. increased consecutively from 2017 to 2019, whereas the percentage of Klebsiella pneumoniae decreased in 2019. Considering carbapenem-resistant (CR) Enterobacterales, an increase of the percentage of CR-K. pneumoniae strains was noticeable. The percentage of CRisolates of Pseudomonas aeruginosa and Acinetobacter spp. varied from 30\% to 38\% and from $81 \%$ to $85 \%$, respectively. Conclusion: The knowledge of the most commonly isolated bacterial pathogens, especially the presence of resistant bacteria, is crucial and should be continuously monitored in order to understand, construct and update effective treatment algorithms and guidelines.
\end{abstract}

\section{Клинички истражувања}

\section{НАЈЧЕСТИ БАКТЕРИСКИ ИЗОЛАТИ ОД ПРИМЕРОЦИ ОД РАНИ - ТРИГОДИШНА СТУДИЈА}

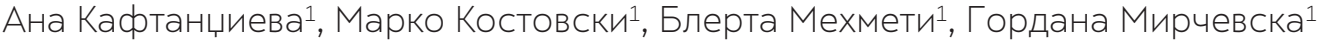

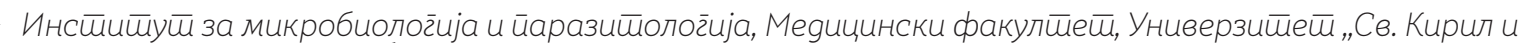 \\ мейоguj" во Скойје, Рейублика Северна Макеgонија
}

Цитирање: Кафтанџиева А, Костовски М, Мехмети Б, Мирчевска Г. Најчести бактериски изолати од примероци од рани - тригодишна студија. Арх Ј Здравје 2021;13(1)

doi.org/10.3889/aph.2021.5736

Клучни зборови: примероци од рани, резис тентни бактерии, Staphylococcus aureus, карбапенем-резистентни бактерии

*Кореспонденција: Ана Кафтанџиева, Институт за микробиологија и паразитологија, Медицински факултет, Универзитет „Св. Ки рил и Методиј” во Скопје, Република Северна Македонија

E-mail: akaftandzieva@yahoo.com

Примено: 16-дек-2020; Ревидирано: 27-фев-2021 Прифатено: 1-мар-2021 Објавено: 8-Јуни-2021

Печатарски права: 2021 Ана Кафтанџиева, Марко Костовски, Блерта Мехмети, Гордана Марко Костовски, Блерта Мехмети, Гордан Мирчевска. Оваа статија е со отворен пристап дистрибуирана под условите на нелокализи рана лиценца, која овозможува неограничена употреба, дистрибуција и репродукција на било кој медиум, доколку се цитираат оригиналниот(ите) автор(и) и изворот.

Конкурентски интереси: Авторот изјавува дека нема конкурентски интереси.

\section{Извадок}

Цел на студијата беше да се детектираат најчестите бактерии изолирани од примероци од рани и да се спореди процентот на резистентни бактерии во тригодишниот период. Материјал и методи: Во период од три години (2017-2019) вкупно 11.863 примероци од рани (брисеви, пунктати, ексудати, ткиво и др.) земени од пациенти хоспитализирани во Универзитетските клиники во кампусот „Мајка Тереза”, Градската болница „,8-ми Септември”, Универзитетската клиника за хируршки болести „Св. Наум Охридски” во Скопје, беа обработени на Институтот за микробиологија и паразитологија, Медицински факултет, Скопје. За обработка беа користени стандардни микробиолошки техники. Идентификацијата на бактериите, како и одредување на нивната осетливост кон антимикробни средства беше направена со стандардни и автоматизирани методи (Vitek 2- систем). Резултати: Од вкупниот број на примероци, кој изнесуваше 3.463 во 2017, 4.127 во 2018 и 4.273 во 2019 год., позитивни беа 2.068 (60\%), 2.302 (55,8\%) и 2.387 (55,9\%), последователно. Најчесто изолирани беа: Staphylococcus aureus, Enterococcus spp, Pseudomonas aeruginosa и E. coli. Процентот на резистентни соеви (MRSA, CNS-MR и VRE) беше речиси идентичен во испитуваниот период. Кај Грам-негативните бактерии беше детектирано зголемување на процентот на ESBL-позитивни соеви на E. coli и Enterobacter spp. во периодот од 2017 до 2019, за разлика од Klebsiella pneumoniae кај која во 2019 беше детектирано намалување на тој процент. Во однос на карбапенем-резистентните (CR) ентеробактерии, кај K. pneumoniae беше детектирано зголемување на процентот на карбапенем-резистентни соеви. Процентот на CR-соеви на Pseudomonas aeruginosa и на Acinetobacter spp варираше меѓy 30\% и 38\%, и меѓу 81\% и 85\%, последователно. Заклучок: Потребно е континуирано мониторирање на најчесто изолираните бактерии од примероците од рани, особено присуството на резистентни бактерии, со цел примена на соодветни алгоритми и водичи за ефективен третман на инфекциите на рани. 


\section{Introduction}

Normal function of skin is to prevent colonization and invasion of underlying tissue by potential microbial pathogens. Loss of skin integrity (wound) provides moist and nutritious environment for microbial proliferation. Microbial colonization precedes wound infection. The common source of microorganisms are exogenous (environmental, surrounding skin), and endogenous (mucous membranes of gastrointestinal tract and genitourinary tract, oropharyngeal cavity). ${ }^{1}$

An important entity in the clinical setting are skin and soft tissue infections (SSI). ${ }^{2}$ Microbes involved in skin and soft tissue infections could differ considering the site of infection. It has been shown that SSI could be community acquired or acquired in the hospital environment. Thus, these infections are characterized with varying etiology, as well as various microbes that could be involved in the pathogenesis of the infection. ${ }^{3}$ The isolation of Gram-positive bacteria has been most commonly associated with acute infections, while microbes that were most commonly isolated from chronic wound were Gram-negative bacteria. ${ }^{4}$ Especially important category among SSI are surgical site infections. It is of note that despite the recent advances in medical technology, in general, these infections could not be always successfully prevented. ${ }^{5}$ These infections could lead to increased morbidity and mortality risk of patients. ${ }^{6}$

The most commonly isolated bacterium from SSI with a significant epidemiological implication is Staphylococcus aureus. Although not as frequent as $S$. aureus, some Gram-negative bacilli (Pseudomonas aeruginosa and Escherichia coli) and other Gram-posi- tive cocci (Enterococcus spp.) have been also identified as frequent causative pathogens of SSI.7 Simple SSI are often regarded uncomplicated and most commonly are monomicrobial, while complicated SSI could range from monomicrobial to polymicrobial. ${ }^{8}$

Predisposing factors to SSI that could lead to the progression of the disease include diabetes mellitus, vascular disease, obesity, trauma, recent surgical intervention, and preexisting immunocompromised condition. ${ }^{9}$ Inadequate initial empirical antibiotic treatment has been considered as a main factor that has been associated with a higher mortality in SSI, pointing out that initial treatment construction should take into consideration Gram-negative bacteria and bacteria that exhibit extended spectrum beta lactamases (ESBL) production as possible causative pathogens. ${ }^{10}$ SSI are often associated with many different complications where gangrene, osteomyelitis, bacteremia, and sepsis being considered as one of the most serious SSI complications. Evidence data suggests that complications and hospitalizations associated with SSI are several times higher in people with diabetes. ${ }^{11,12}$

Treatment options for uncomplicated SSI would require empiric treatment and usually the antibiotics used should have antimicrobial effect against Staphylococci and Streptococci, while complicated SSI would require more serious approach integrating hospital treatment that will include wound debridement together with the use of broad-spectrum antibiotics. ${ }^{13}$

Increase in the misuse and mismanagement of antibiotics which are now leading to drug resistance is creating a lot of concern in medical practice. The current spread of multi-drug re- 
sistant (MDR) bacteria poses a major threat to patients' treatment as it leads to increased morbidity and mortality, increased hospital stay, and severe economic implications. ${ }^{14}$

Therefore, early microbiological diagnosis of SSI is of high importance and should be considered imperative. The knowledge of the most commonly isolated bacterial pathogens is crucial and should be continuously monitored in order to understand, construct and update effective treatment algorithms and guidelines. ${ }^{15}$

The aim of our study was to determine the most common bacteria isolated from wound samples and to compare the frequency of the resistant bacteria isolated over a 3-year period.

\section{Material and methods}

In a three-year period $(2017,2018,2019)$ a total of 11863 wound samples (wound swabs, punctuates, exudates, tissue, drain swabs, breast swabs, umbilical swabs) were obtained from the hospitalized patients in the University Clinical Center "Mother Theresa", the City hospital " $8^{\text {th }}$ September" and the University Clinic for Surgical Diseases "St. Naum Ohridski" in Skopje.

For isolation and identification of microorganisms, standard media were used (Columbia agar with 5\% sheep blood for the isolation of aerobes, Schaedler agar for the isolation of anaerobes, glycose broth for enrichment of the growth and Candida albicans (CALB) agar for the isolation of yeasts) and standard biochemical tests were performed. Columbia agar plates were incubated for 24 hours, Schaedler agar plates for 48 hours, while CALB agar plates were incubated longer (2-3 days) at $37^{\circ} \mathrm{C}$.

Disc diffusion method was used for determination of the susceptibility of Gram-positives and Gram-negatives to antimicrobial agents. The combination of antibiotic discs and the interpretation of the results were done according to the European Committee on antimicrobial susceptibility testing (EUCAST) criteria. E-tests were performed to determine minimal inhibitory concentrations (MIC) values of vancomycin and colistin. Automatized Vitek 2 system (bioMerieux) was used for identification of all anaerobes and confirming the identification and susceptibility to antibiotics for the aerobes. For routine Quality Control of antibiotic susceptibility test, S. aureus ATCC 25923 and E. coli ATCC 25922 were used.

Additional tests were performed for identification of the multidrug resistant bacteria (MDR), such as: cefoxitine disc $30 \mu \mathrm{g}$ for the confirmation of methicillin resistant Staphylococcus aureus (MRSA), double disc synergy test as screening for extended-spectrum beta-lactamases (ESBLs) producing Enterobacterales and carbapenem inactivation method (CIM) and combination discs test (Mast Diagnostic, D70C) as screening for carbapenemresistant Enterobacterales. Detection of carbapenem resistant non-fermentatives was done by zone diameters of carbapenems (imipenem, meropenem) and the values of MIC.

The results of our study are presented as numbers and percentages. The annual rates of MRSA, methicillin resistant (MR) coagulase negative Staphytlococcus (CoNS-MR), vancomycin resistant Enterococcus (VRE), carbapenem resistant enterobacteria and non-fermentatives over the three-year period were compared by Pearson Chi square test. $P$ value $\leq 0.05$ was considered statistically significant. 


\section{Results}

In 2017, of a total of 3,463 samples, 2,068 (60\%) were positive with 2971 isolated microorganisms. Of these, 2,758 were aerobic bacteria: 1,420 Gram-positive, 1,338 Gram-negative, 99 were anaerobic bacteria, 108 were yeasts and only 5 were molds. In 2018, of a total of 4,127 samples, 2,302 (55.8\%) were positive with 3,178 isolated microorganisms. Of these, 2,949 were aerobic bacteria: 1,476 Gram-positive, 1,473 Gram-negative, 114 were anaerobic bacteria, 108 were yeasts and 7 were molds. In 2019, of a total of 4,273 samples, 2,387 (55.9\%) were positive with 3,583 isolated microorganisms. Of these, 3,279 were aerobic bacteria: 1,610 Gram-positive, 1, 669 Gram-negative, 157 were anaerobic bacteria, 136 were yeasts and 11 were molds. These results are presented in Figure 1.

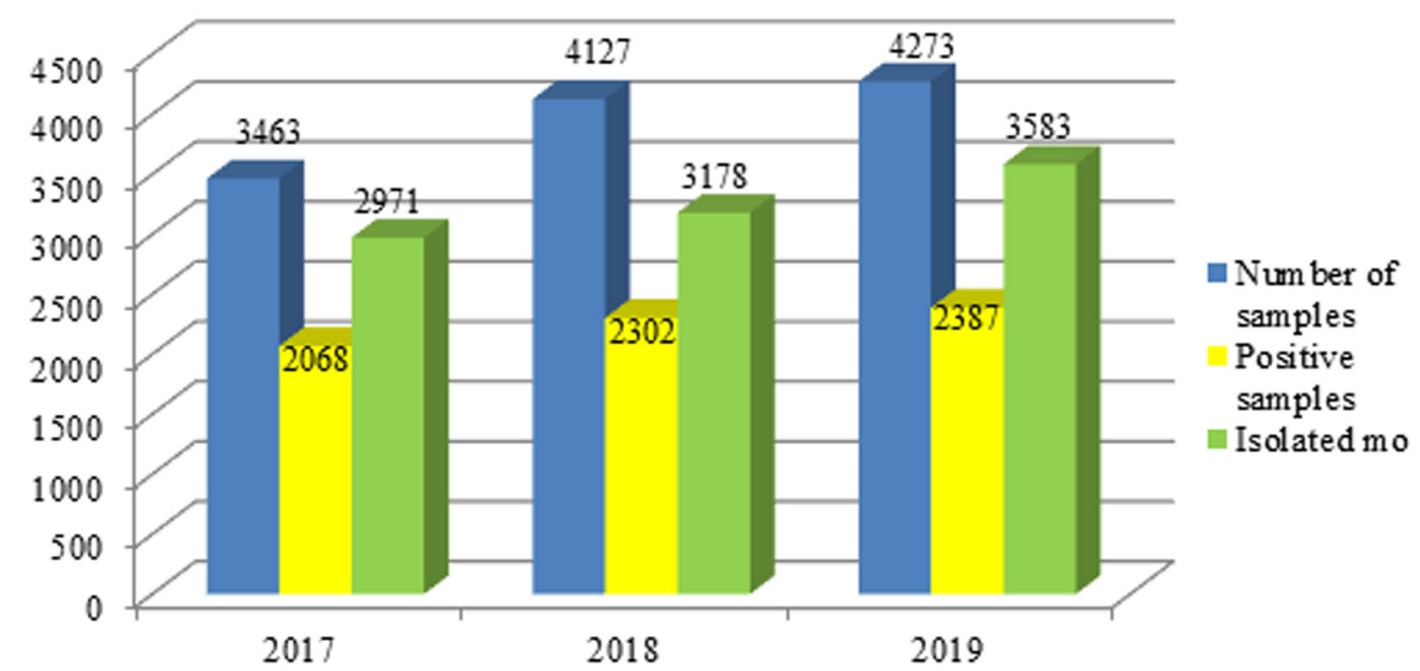

Figure 1: Total number of samples, number of positive samples and number of isolated microorganisms in a 3-year period

As it can be seen from Figure 2, both increased from year to year. There has the number of samples as well as the been an increasing trend, without any number of positive samples with a to- major difference between the years. tal number of microorganisms have

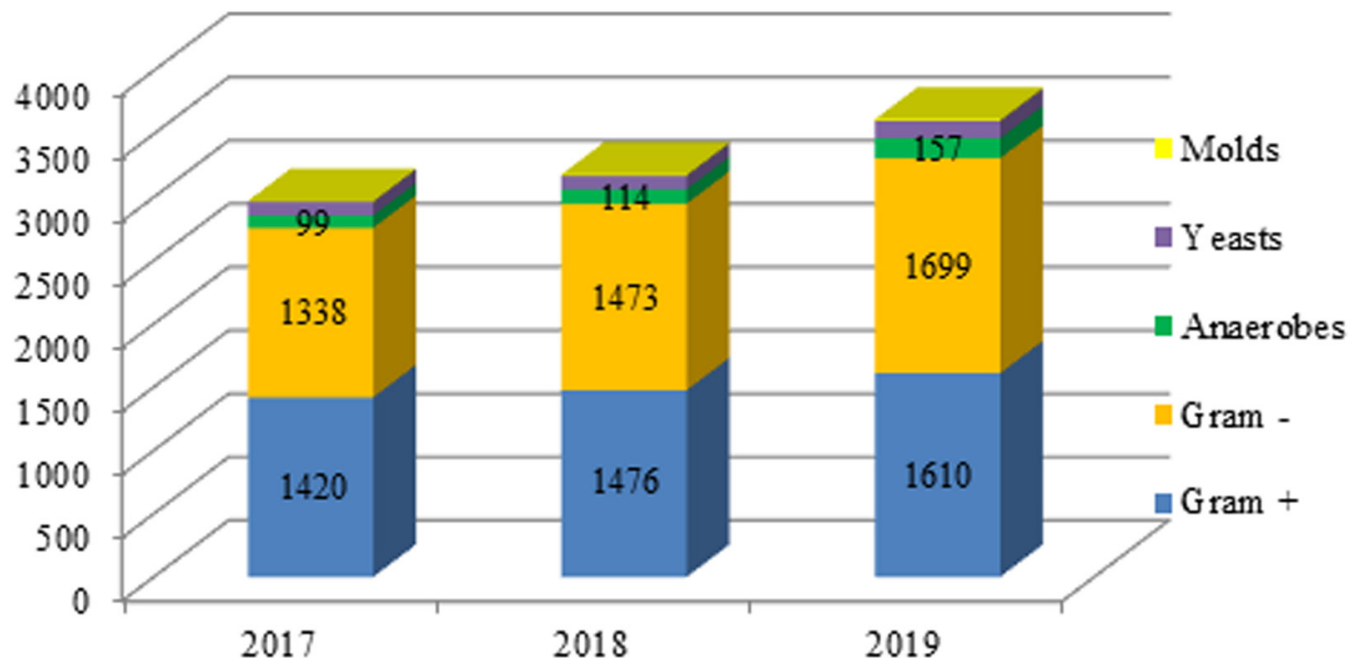

Figure 2: Total number of different microorganisms isolated in a 3-year period 
Despite the increase in the total number of microorganisms from year to year, the ratio between Grampositives and Gram-negatives has changed. Namely, in 2017 the number of Gram-positives was higher than that of Gram-negatives $(1,420$ vs. 1,338$)$, in the next year, the num- bers were almost identical (1,476 vs. 1473), whereas in 2019 the number of Gram-negatives was higher 1,699 vs. 1,610). The most common bacteria (aerobes and facultative anaerobes) isolated from wound samples are shown in Table 1.

Table 1: Ten most common bacteria (aerobes and facultative anaerobes) from wound samples

\begin{tabular}{|c|c|c|c|}
\hline $\begin{array}{l}\text { Gram-negative } \\
\text { bacteria }\end{array}$ & $\begin{array}{c}2017 \\
\text { Total } 1420 \\
\text { N }(\%)\end{array}$ & $\begin{array}{c}2018 \\
\text { Total } 1476 \\
\text { N }(\%)\end{array}$ & $\begin{array}{c}2019 \\
\text { Total } 1610 \\
\text { N }(\%)\end{array}$ \\
\hline Staphylococcus aureus & $537(38 \%)$ & $491(33 \%)$ & $553(34 \%)$ \\
\hline Enterococcus & 439 (31\%) & $473(32 \%)$ & $550(34 \%)$ \\
\hline Coag. neg. Staphylocoсcus & 245 (17\%) & $317(22 \%)$ & $252(16 \%)$ \\
\hline Corynebacterium & $120(9 \%)$ & $113(8 \%)$ & $143(9 \%)$ \\
\hline $\begin{array}{l}\text { Gram-negative } \\
\text { bacteria }\end{array}$ & $\begin{array}{c}2017 \\
\text { Total 1338 } \\
\text { N }(\%)\end{array}$ & $\begin{array}{c}2018 \\
\text { Total 1473 } \\
\text { N }(\%)\end{array}$ & $\begin{array}{c}2019 \\
\text { Total 1669 } \\
\text { N }(\%)\end{array}$ \\
\hline Pseudomonas aeruginosa & $327(24 \%)$ & $381(26 \%)$ & $416(25 \%)$ \\
\hline E.coli & $273(20 \%)$ & $308(21 \%)$ & $352(21 \%)$ \\
\hline Acinetobacter spp. & $198(15 \%)$ & $190(13 \%)$ & $284(17 \%)$ \\
\hline Enterobacter spp. & $212(16 \%)$ & $187(13 \%)$ & $166(10 \%)$ \\
\hline Proteus mirabilis & $105(8 \%)$ & $126(9 \%)$ & $144(9 \%)$ \\
\hline Klebsiella pneumoniae & $89(7 \%)$ & $165(11 \%)$ & $138(8 \%)$ \\
\hline
\end{tabular}

The most commonly isolated (more than 10\%) Gram-positive bacteria were: Staphylococcus aureus, Staphylococcus coagulase negative and Enterococcus. Considering Gramnegative bacteria, Pseudomonas aeruginosa and E. coli were the most commonly isolated (in almost identical proportions over three years), followed by Acinetobacter (higher in 2019 compared to the previous two years), Enterobacter (higher in 2017 compared to the other two years) and Klebsiella (in a higher percentage in 2018, compared to the other two years).
From the total aerobes/facultative anaerobes $(2,758,2,949$ and 3,279 in the three consecutive years, 2017, 2018 and 2019, respectively), Staphylococcus aureus was the most predominant isolate $(19.5 \%, 16.6 \%$, 16.9\%) followed by Enterococcus spp (16\%, 16\%, 16.7\%), Pseudomonas aeruginosa $(12 \%, 13 \%, 12.7 \%)$ and E. coli $(10 \%, 10.4 \%, 10.7 \%)$.

The number of anaerobic bacteria was constantly increasing to such an extent that in 2019 it was 63\% higher than the number in 2017 (157 vs. 99). The percentage of Grampositive anaerobes (Peptostrepto- 
coccus) decreased from $33 \%$ to $18 \%$ oof a total number of anaerobes. In the case of Clostridium spp. this percentage increased from $5 \%$ to $13 \%$. The percentage of Gram-negative anaerobes also increased, which was mostly observed in bacteria of the genus Bacteroides (from 39\% to $45 \%$ of the total number of isolated anaerobes for each year). The percentage of Bacteroides fragilis of the total number of the genus Bacteroides increased from 49\% in 2017 to 82\% in 2019 (Table 2).

Table 2: The most common anaerobic bacteria isolated from wound samples

\begin{tabular}{|c|c|c|c|}
\hline \multirow{2}{*}{ Anaerobes } & $\begin{array}{c}2017 \\
\text { Total } 99\end{array}$ & $\begin{array}{c}2018 \\
\text { Total } 112\end{array}$ & $\begin{array}{c}2018 \\
\text { Total } 157\end{array}$ \\
\hline & $\mathrm{N}(\%)$ & $\mathrm{N}(\%)$ & $\mathrm{N}(\%)$ \\
\hline Peptostreptococcus & $33(33 \%)$ & $28(25 \%)$ & $28(18 \%)$ \\
\hline Peptococcus & $17(17 \%)$ & $17(15 \%)$ & $30(19 \%)$ \\
\hline Clostridium spp & $5(5 \%)$ & $6(5 \%)$ & $21(13 \%)$ \\
\hline $\begin{array}{c}\text { Bacteroides spp. } \\
\text { (B. fragilis) }\end{array}$ & $\begin{array}{c}39(39 \%) \\
(19)\end{array}$ & $\begin{array}{c}51(46 \%) \\
(35)\end{array}$ & $\begin{array}{c}71(45 \%) \\
(58)\end{array}$ \\
\hline Prevotella spp & $1(1 \%)$ & $3(3 \%)$ & 1 \\
\hline Fusobacterium & $1(1 \%)$ & 1 & $3(2 \%)$ \\
\hline Other anaerobic bacilli & $3(3 \%)$ & $7(6.3 \%)$ & $4(2.5 \%)$ \\
\hline
\end{tabular}

When comparing the results of strains of MRSA, CoNS-MR and VRE MDR Gram-positive bacteria in the was almost the same in that period. three-year period, it can be noticed This difference was not statistically that the percentage of the resistant significant ( $<<0.05)$ (Fig. 3).

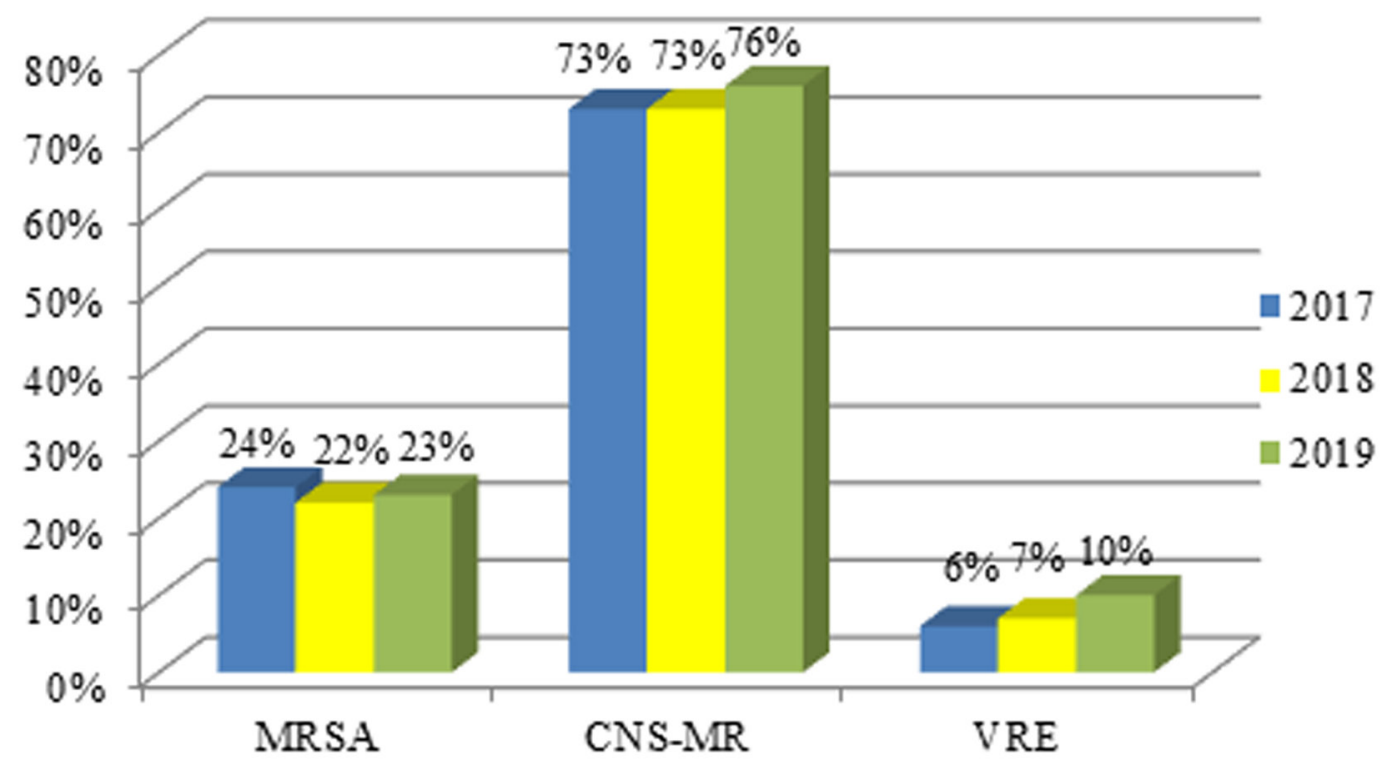

Figure 3: Percentage of resistant Gram-positive bacteria in a three-year period 
In Gram negatives, the percentage of ESBL-positive isolates of E. coli and Enterobacter spp. increased consecutively from 2017 to 2019. Even though this difference was obvious, it was not statistically significant $(\mathrm{p}>0.05)$. The increase in the percentage of resistant strains was more noticeable in ESBLpositive isolates of Klebsiella pneumoniae between 2017 and 2018, but in 2019 a decrease in the percentage can be observed (Figure 4).

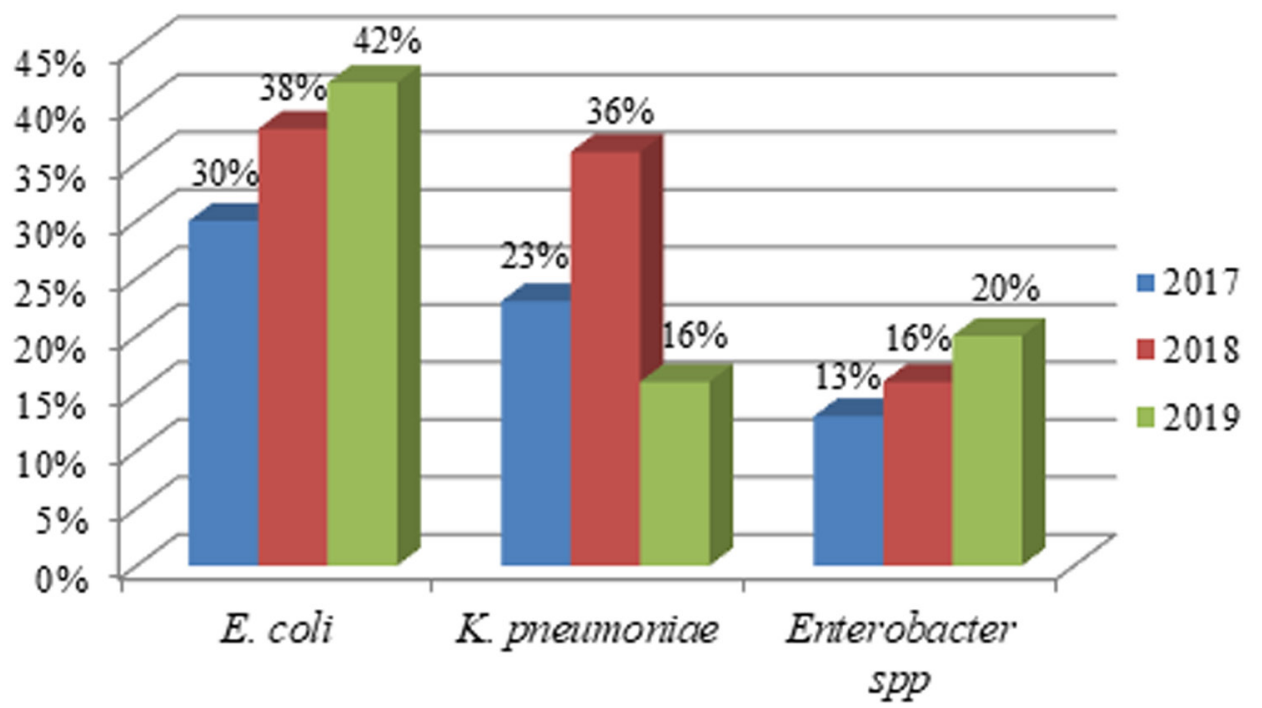

Figure 4: Comparison of percentage of ESBL-positive bacteria of Enterobacterales family in a 3-year period

Considering carbapenem-resistant (CR) Enterobacterales, an increase in the resistance was noticeable in $K$. pneumoniae, but it was not statistically significant ( $\mathrm{p}>0.05)$. The increase in the percentage of resistant strains in Enterobacter spp. between 2017 and 2018 as well as the decrease between 2018 and 2019 was statistically significant ( $p$ $<0.05$ ) (Figure 5).
Contrary to the results obtained for CR Enterobacterales, in the case of Pseudomonas aeruginosa, the percentage of CR-isolates decreased from 38\% to 30\% and then increased to $35 \%$. Considering Acinetobacter spp. the percentage of CR-isolates slightly increased from $81 \%, 83 \%$ to $85 \%$ in 2019 ( $p$ > 0.05) (Figure 5).

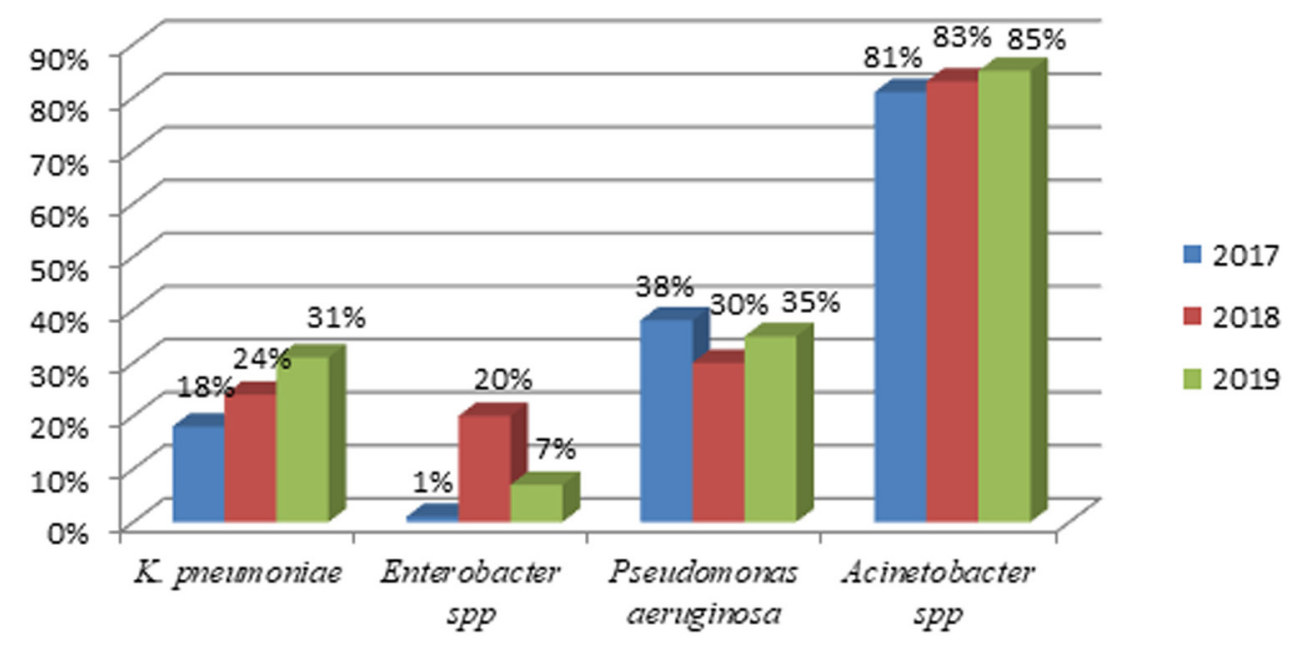

Figure 5: Carbapenem-resistant Gram-negative bacteria (Enterobacterales - $K$. pneumoniae and Enterobacter spp and non-fermentatives - P. aeruginosa and Acinetobacter spp) 


\section{Discussion}

Our study was conducted in a period of three years and an increasing trend in the number of samples, the number of positive samples, as well as the number of isolated microorganisms was observed. In another study of ours conducted in 2002, the total number of wound samples for one year was 1,970, which was less than twice compared to 2019, in which period the number of wound samples was 4,273 . This may indicate an increased awareness of clinicians to send samples for microbiological analysis in order to identify the etiological agent of the wound infection and to prescribe appropriate antimicrobial therapy. ${ }^{16}$ In our study, of the total number of all examined samples the percentage of positivity varied between 56\% $60 \%$. It indicates that almost every other sample was with one or more isolated microorganisms. A sample should always be taken when clinical signs of infection are present, but also in case when a wound does not heal. Other studies reveal that incidence of positive culture varies from $30 \%$ to $70 \%$ or even $86 \%$. The possible explanation for these differences might be due to the study design. The rates might be equally high if only wounds with a high suspicion of infection are examined, and not all wounds. . $^{17,18,19,20}$

In our study, of the total number of Gram-positive bacteria, the most common were: Staphylococcus aureus and Enterococcus. Of the total number of Gram-negative bacteria, the most common were: Pseudomonas aeruginosa, followed by E. coli, Acinetobacter, Enterobacter, and Klebsiella pneumoniae. Other stud- ies have also reported that Staphylococcus aureus was the most common wound isolate. ${ }^{21,22,23} \mathrm{~S}$. aureus is normal flora of the skin and anterior nares, therefore it can easily contaminate wounds and cause infections. Moreover, $S$. aureus is known to have a vast number of virulence factors that increase its ability to cause infections when compared to other bacteria. These findings are in contrast to the study conducted in a similar setting where Pseudomonas aeruginosa was the commonest isolate in surgical site infections. These variations could be attributed to several factors including the nature of the surgical site itself, the wound site, the type of prophylactic antibiotics used for infections prevention, the level of nursing care given and the measures taken to prevent nosocomial infections. ${ }^{24}$ Other studies also reported Gramnegative bacteria as predominant microbes.19,20 This might be due to high resistances to antibiotics showed by Gram-negative bacteria compared to Gram-positive isolates, and therefore their persistence in infected wounds. Furthermore, chronic wounds were infected by multiple Gram-negative rods. ${ }^{25}$ Similar studies revealed that Gramnegatives were more prevalent than the Gram-positives with the prevalence of $70 \%$ and $30 \%$, respectively. Pseudomonas spp. was the most common isolated Gram-negative bacilli, while $S$. aureus was the most common Gram-positive bacteria. The trend in the rate of isolation of Gram-negative bacilli over the study period increased, while the trend of Gram-positive bacteria isolates decreased. Although these changes were not statistically significant, 
they were clinically important. ${ }^{26}$ These findings are consistent with the findings of our study. Other studies present similar findings. Gram-negatives were $57 \%$ of the isolates and $43 \%$ were Gram-positives. From the total isolates, Staphylococcus aureus was the most predominant isolate (34\%), followed by Klebsiella spp. (13\%), coagulase negative Staphylococci spp. (12\%) and Pseudomonas aeruginosa. ${ }^{27}$ Polymicrobial infection was found in $27 \%$ of the samples and was mainly presented with two species. The most common association was $S$. aureus/P. aeruginosa. Gram-negatives showed very high resistance to the majority of examined antibiotics. ${ }^{28,29}$

The percentage of Bacteroides fragilis of the total number of the genus Bacteroides increased from $49 \%$ in 2017 to $82 \%$ in 2019. Detection of $B$. fragilis is important because of the choice of an appropriate therapy. Namely, this species has inherited a high-level resistance to penicillin. Production of beta-lactamase appears to be the main mechanism of antibiotic resistance in B. fragilis. Clindamycin is no longer recommended as the first-line agent for B. fragilis due to emerging high-level resistance ( $>30 \%$ in some reports). ${ }^{30}$ Anaerobic bacteria coexist with the aerobic bacteria. In our study, the principal isolates were Bacteroides spp, Peptococci, Proteus spp, Enterococci, Staphylococcus aureus, Clostridia, and E. coli. When antimicrobial therapy is indicated the selection of agents should consider the likelihood of a complex aerobic-anaerobic flora. ${ }^{31,32}$ The highest rates of anaerobes in wounds were in the inguinal, buttocks, and trunk areas and in abscesses in the peri- rectal, external genitalia, neck, and inguinal areas. The predominant were Bacteroides species, Peptostreptococcus species, Clostridium species, and Fusobacterium species. The predominance of certain isolates in certain anatomical sites was correlated with their distribution in the normal flora adjacent to the infected site. These data highlight the polymicrobial nature of wounds and cutaneous abscesses. ${ }^{33}$

When comparing the results of MDR Gram-positive bacteria in a threeyear period, it can be noticed that the percentage of the MRSA strains was almost the same in that period (from $21 \%$ to $23 \%$ ). Nosocomial infections acquired by patients receiving institutional healthcare have long been the classical presentation of MRSA infections. Risk factors for MRSA acquisition include hospital care, care in chronic care facilities and nursing homes for elderly people, presence of indwelling devices or chronic wounds and previous antibiotic treatment. Pan-European surveillance data on bloodstream infections show marked variability among EU Member States in the proportion of $S$. aureus that are methicillin-resistant, ranging from less than $1 \%$ to more than $50 \%{ }^{34}$

Coagulase-negative staphylococci (CoNS) are opportunistic pathogens that persist and multiply on a variety of environmental surfaces. It is the cause of both nosocomial and community acquired infections worldwide. The prevalence of methicillin-resistant coagulase negative staphylococci (MR-CoNS) has been reported. In addition, biofilm production by CoNS has been identified as an important factor of pathogen- 
esis, protecting against antibiotics and the immune system. The conversion of the CoNS from symbiont to human pathogen has been a direct reflection of the use of indwelling medical devices. ${ }^{35}$ In our study, CNS was detected in $9 \%-11 \%$ of the total number of bacterial isolates in the examined period and the percentage of MR-CoNS of the total number of CoNS ranged between $73 \%$ and $75 \%$.

Extended-spectrum beta-lactamases (ESBLs) have been increasingly reported in Europe since their first description in 1983. During the 1990s, they were described mainly in Klebsiella pneumoniae causing nosocomial outbreaks. Among MDR bacterial infections, E. coli has the resistance rates up to $38 \%$ against broad-spectrum cephalosporins in Southern and Eastern Europe via extended-spectrum beta-lactamases. For Klebsiella pneumoniae, the highest figures come from Greece (70.1\%) and Serbia (88\%). ${ }^{36}$ Similar results were found in our study. Namely, the percentage of ESBL-positive isolates of E. coli (30\%-42\%) and Enterobacter spp. (13\%-20\%) increased from 2017 to 2019. The increase in the percentage of resistant strains was more noticeable in ESBL-positive isolates of Klebsiella pneumonia between 2017 and 2018 (from 23\% to $36 \%$ ), unlike 2019 when that percentage decreased from $36 \%$ to $16 \%$. It is the excessive use of third-generation cephalosporins in a hospital setting that has contributed to the selection of these strains. This is assumed to be the case in our hospital setting as well. Carbapenems are the drugs of choice in the treatment of infections caused by these strains. It is their more frequent application in clinical practice that leads to a new problem, which is the emergence of carbapenem-resistant strains.

For K. pneumoniae, data from the European Antimicrobial Resistance Surveillance Network (EARS-Net) for 2017 showed large variability in the national percentages of carbapenem resistance (CR) in isolates from invasive infections, ranging from $0 \%$ to $64.7 \%$. For E. coli, EARSNet data for 2017 showed a lower mean percentage $(0.1 \%)$ of carbapenem resistance in invasive isolates, with national percentages ranging from $0 \%$ to $1.6 \%$. Carbapenem resistance in E. coli is rare in Europe, but has become prevalent in K. pneumoniae $59.4 \%$ in Greece, $34.3 \%$ in Italy, 20.5\% in Romania, and less than $2 \%$ in other EU countries). ${ }^{36,37}$ In our study, there was an increase in the percentage of carbapenem-resistant Klebsiella pneumoniae from 18\% to $34 \%$ and of Enterobacter spp. from $1 \%-20 \%$. Not a single carbapenemresistant isolate of $E$. coli has been isolated from wound samples at our Institute so far.

The rates of carbapenem resistance in non-glucose-fermenting Gramnegative bacilli have been gradually increasing worldwide over the last 10 years and vary geographically. ${ }^{19,20}$ These increases in carbapenem resistance among non-fermentatives can be attributed to multiple factors, such as the increased use of broad-spectrum antibiotics (including the carbapenems), the use of indwelling medical devices, an increase in immunocompromised host populations, and the acquisition of carbapenemases. Carbapenem resistance rates among $P$ seu- 
domonas aeruginosa isolates in most countries range from $10 \%$ to $50 \%$ and was reported as low as $3.3 \%$ in Canada to 50\% in Russia, Southwest Asia, and South America. Carbapenem resistance was reported in more than $50 \%$ of isolates of Acinetobacter baumannii in Portugal, Greece, Italy, Cyprus, Romania and Bulgaria. ${ }^{36,38,39,40}$ In our study the percentage of CR-isolates of Pseudomonas aeruginosa varied from 35\%-38\%. The percentage of CR-isolates of Acinetobacter spp. slightly increased from $81 \%$ to $85 \%$. If carbapenem resistance becomes more widespread, therapeutic options may become tragically few. Thus, in 2013, these multidrug-resistant (MDR) organisms were identified as a serious public health threat by the Centers for Disease Control and Prevention (CDC). ${ }^{41}$

\section{Conlusions}

In conclusion, the most commonly isolated potential pathogens from wound specimens were bacteria from the genus Staphylococcus and Enterococcus, followed by Pseudomonas aeruginosa and E. coli. Monitoring of the microbial flora in the wounds, especially the presence of resistant bacteria, such as MRSA, ESBL-producing isolates of Enterobacterales family, as well as carbapenem-resistant bacteria is important for the application of appropriate antimicrobial therapy. It is desirable to institute protocols for antimicrobial prophylaxis and treatment as well as for duration of their use in the hospital settings in addition to the knowledge of bacterial resistance pattern. The implementation of such protocols, implementation of infection control measures as well as the constant communication between the microbiologists and the clinicians will reduce the overall prevalence of bacterial wound infection and will enable their adequate treatment.

\section{References}

1. Bowler PG, Duerden BI, Armstrong DB. Wound microbiology and associated approaches to wound management. Clinical Microbiology Reviews 2001;14:244-269.

2. Ki V, Rotstein C. Bacterial skin and soft tissue infections in adults: A review of their epidemiology, pathogenesis, diagnosis, treatment and site of care. Can J Infect Dis Med Microbiol 2008;19(2):173-184.

3. Eron LJ, Lipsky BA, Low DE, Nathwani D, Tice AD, Volturo GA; Expert panel on managing skin and soft tissue infections. Managing skin and soft tissue infections: expert panel recommendations on key decision points. J Antimicrob Chemother 2003;52 Suppl 1:i3-17.

4. Cardona AF, Wilson SE. Skin and soft-tissue infections: a critical review and the role of telavancin in their treatment. Clin Infect Dis 2015;61 Suppl 2:S69-78.

5. Maier S, Körner $P$, Diedrich $S$, Kramer A, Heidecke CD. Definition and management of wound infections]. Chirurg 2011;82(3):23541.

6. Onyekwelu I, Yakkanti R, Protzer L, Pinkston CM, Tucker C, Seligson D. Surgical Wound Classification and Surgical Site Infections in the Orthopaedic Patient. J Am Acad Orthop Surg Glob Res Rev 
2017;1(3):e022.

7. Esposito S, Noviello S, Leone S. Epidemiology and microbiology of skin and soft tissue infections. Curr Opin Infect Dis 2016;29(2):109-15.

8. M. Ibáñez Barceló, V. Pomar Solchaga, S. Castañeda. Infecciones de partes blandas. Med Clín 2009;133:139-146.

9. Macía-Rodríguez C, Alende-Castro V, Vazquez-Ledo L, Novo-Veleiro I, González-Quintela A. Skin and softtissue infections: Factors associated with mortality and re-admissions. Enferm Infecc Microbiol Clin 2017;35(2):76-81.

10. Ramakrishnan K, Salinas RC, Agudelo Higuita NI. Skin and Soft Tissue Infections. Am Fam Physician 2015;92(6):474-83.

11. Ebright JR, Pieper B. Skin and soft tissue infections in injection drug users. Infect Dis Clin North Am. 2002;16(3):697-712.

12. Ramakrishnan K, Salinas RC, Agudelo Higuita NI. Skin and Soft Tissue Infections. Am Fam Physician. 2015;92(6):474-83.

13. Li X, Chen Y, Gao W, Ouyang W, Wei J, Wen Z. Epidemiology and Outcomes of Complicated Skin and Soft Tissue Infections among Inpatients in Southern China from 2008 to 2013. PLoS One. 2016;11(2):e0149960.

14. Basak S. et al. Multidrug resistant and extensively drug resistant bacteria: a study. Journal of pathogens 2016, article ID 4065603.

15. Li X, Chen Y, Gao W, Ouyang W, Wei J, Wen Z. Epidemiology and Outcomes of Complicated Skin and Soft Tissue Infections among
Inpatients in Southern China from 2008 to 2013. PLoS One. 2016;11(2):e0149960.

16. Kaftandzieva A et al. Bacteriology of Wound - Clinical Utility of Gram Stain Microscopy and the Correlation with Culture. Macedonian Journal of Medical Sciences 2012;5(1):72-74.

17. Taiwo S, Okesina A, Onile B. In vitro antimicrobial susceptibility pattern of bacterial isolates from wound infections in University of Ilorin Teaching Hospital. Afr J Clin Exp Microbiol 2002; 3(1): 6-10.

18. Mulugeta KA, Bayeh A. Bacteriology and antibiogram of pathogens from wound infections at Dessie Laboratory, North East Ethiopia. Tanz J Health Res 2011;13(4).

19. Farrag HA, El-Rehim HA, Hazaa MM, et al. Prevalence of Pathogenic Bacterial Isolates Infecting Wounds and their Antibiotic Sensitivity. J Infec Dis Treat 2016; 2:2.

20.Alwan MJL, Hamzah AM. Bacterial isolation from burn wound infections and studying their antimicrobial susceptibility. Kufa Journal for veterinary medical sciences 2011;2:121-131.

21. Onche I, Adedeji O. Microbiology of post-operative wound infection in implant surgery.

22. Niger J Surg Res 2004;6(1):37-40.

23. Sonawane J, Kamath N, Swaminathan R, Dosani K. Bacterial profile of surgical site infections and

24. their antibiograms in a tertiary care hospital. Bombay Hosp J 2010;52:358-61.

25. Maksimovic J, Markovic-Denic L, 
Bumbasirevic M, Marinković J, Vlajinac H. Surgical site infections in orthopedic patients: prospective cohort study. Croat Med J 2008;49(1):58-65.

26. Shriyan A, Sheetal R, Nayak N. Arobic micro-organism in postoprative wound infection and their antimicrobial susceptibility patterns. J Clin Diagn Res 2010;3:2208-2216.

27. Kassam N, Damian D, Kajeguka D, Nyombi B, Kibkiki G. Spectrum and antibiogram of bacteria isolated from patients presenting with infected wounds in a tertiary hospital, northern Tanzania. BMC Res Notes 2017; 10: 757 doi: 10.1186/ s13104-017-3092-9

28. Thanni L, Osinubepi O, Deji M. Prevalence of bacterial pathogens in infected wounds in a tertiary hospital, 1995-2001: any change in trend?. J Natl Med Assoc 2003;95:1189-1195.

29. Mohammed A, Seid ME, Gebrecherkos T, Tiruneh M, Moges F. Bacterial isolates and their antimicrobial susceptibility patterns of wound infections among inpatients and outpatients attending the University of Gondar Referral Hospital, Northwest Ethiopia. International Journal of Microbiology 2017;2017:8953829.

30. Bessa L, Fazii P, Giulio MD, Cellini L. Bacterial isolates from infected wounds and their antibiotic susceptibility pattern: some remarks about wound infection. Int Wound J 2015;12(1): 47-52.

31. Saltoglua $\mathrm{N}$ et al. Influence of multidrug resistant organisms on the outcome of diabetic foot infection. International Journal od
Infectious diseases 2018;70:10-14.

32. Brook I. Treatment of anaerobic infection. Expert Rev Anti Infect Ther 2007;5 (6): 991-1006.

33. Murphy EK, Frick IM. Gram-positive anaerobic cocci - commensals and opportunistic pathogens. FEMS Microbiol Rev 2013;37:520-553.

34. Charles P, Uckay I. Kressmann B, Emonet S, Lipsky A. The role of anaerobes in diabetic foot infections. Anaerobe 2015;34:8-13.

35. Brook I, Frazier E. Aerobic and anaerobic bacteriology of wounds and cutaneous abscesses. Arch Surg 1990;125 (11):1445-1451.

36. Köck R, Becker K, Cookson B, van Gemert-Pijnen JE, Harbarth S, Kluytmans J et al. Methicillinresistant Staphylococcus aureus (MRSA): burden of disease and control challenges in Europe. Euro Surveill 2010;15(41):pii=19688.

37. Seng R, Kitti T, Thummeepak R, Kongthai P, Leungtongkam U, Wannalerdsakun S, et al. Biofilm formation of methicillin-resistant coagulase negative staphylococci (MR-CoNS) isolated from community and hospital environments. PLoS ONE 2017;12(8): e0184172.

38. Dimopoulos G, Akova M. An overview on severe infections in Europe. Intensive Care Med. 2017;43:686-689.

39. European Centre for Disease Prevention and Control. C a r b a p e n e m - r e s i s t a n t Enterobacteriaceae, second update - 26 September 2019. ECDC: Stockholm; 2019.

40.Hong DJ, Bae IK, Jang IH, Jeong SH, Kang HK, Lee K. Epidemiology and characteristics of metallo-_- 
lactamase-producing Pseudomonas

aeruginosa. Infect Chemother 2015;47:81-97.

41. Kim UJ, Kim HK, An JH, Cho SK, Park KH, Jang HC. Update on the epidemiology, treatment, and outcomes of carbapenem-resistant Acinetobacter infections. Chonnam Med J 2014;50:37-44.

42. Gniadnek T, Caroll K, Simner P. Carbapenem-Resistant Glucose Non-Fermenting Gram-Negative Bacilli: The Missing Piece to the Puzzle. Journal of Clinical Microbiology 2016;54(7):1700-1710.

43. Centers for Disease Control and Prevention. Antibiotic resistance threats in the United States, 2013. Centers for Disease Control and Prevention, Atlanta, GA. Available at http://www. cdc.gov/drugresistance/pdf/arthreats-2013-508.pdf. 